\title{
Status of Ginger Wilt and Identification of the Causal Organism in Southern Nations Nationality and People Sates of Ethiopia
}

\author{
Bekelle Kassa(PhD) ${ }^{1}$, Habetewold kifelew ${ }^{2}$, Tariku Hunduma ${ }^{3}$, Kasahun Sadessa $^{3}$ \\ ${ }^{1}$ Holetta Agricultural Research Center \\ ${ }^{2}$ Tepi National Spice Research Center, Tepi, SNNPRS, Ethiopia \\ ${ }^{3}$ Ambo Plant Protection Research Center \\ bkassa74@yahoo.com,kifelew@yahoo.com
}

\begin{abstract}
Unacquainted disease was reported at epidemic level in ginger crop in southwestern part of Ethiopia and induces heavy annual losses. To quantify the distribution of the disease, survey was conducted in Southern Nation Nationality and People Sate zones in 2012-and 2014 main crop season and covered 11 zones. In ginger farmers' and private farm fields, it was observed that some plants with pathogenicity symptoms including yellowing of leaves and wilting, stunting growth and chlorosis. The prevalence of the disease was $100 \%$ but the mean maximum incidence was recorded in Sheka zone, 93.5\%, followed by Benchmajizone, $91.6 \%$, while the lowest wilt incidence was recorded in Gamogofa zone $10.7 \%$. During 2014 season wilt incidence was increased to $98.9 \%$ and $97.4 \%$ in Benchmaji zone and Sheka zone respectively. In the same season $78.4 \%$ was recorded in Keffa zone. Alongside some studies was carried out to identify the causal organism of the disease; pathogenicity test and classify the strains on biovars, types and races. The result showed that the pathogen isolated and inoculated on disease free ginger plant generated from rhizomes produced through tissue culture have been developing identical symptoms to the symptom observed on the diseased plants at field conditions. Cultural characteristics of isolates on Tetrazolium Chloride (TZC) Agar selective medium showed light to red color with the characteristic red center which resembles the pathogen Ralstoniasolanascearum. Biochemical and physiological characteristic revealed that similarities among isolates and strains were grouped in biovar III and corresponds to race 4 of the pathogen.
\end{abstract}

Keywords: survey, ginger bacterial wilt, Ralstoniasolanascearum, bivar III, race 4

\section{INTRODUCTION}

Ginger is one of the most important spices, largely for small scale farmer in Ethiopia. The crop is mainly grown in the southern part of the country and it is dominant in the cropping system. In the Southern Nations and Peoples' regional states (SNNPRS), $85 \%$ of the total arable land often allotted for ginger production and 35\% of the farmers in the region produce ginger (Endrias and Asfaw, 2011). From 2006 to 2008 a total of 0.41 million ton of fresh gingers have been produced from an area of 27,229 hectare in limited woredas in the region with a mean yield of 1.6 ton ha -1 . The yield per unit area is low by any standard; however, the land under the crop has increased faster. This vividly shows the important role ginger plays in export market for the country and help to generate income at house hold level. The low yield may be attributed mainly to the absence of seed scheme in the country lead to inter alias to increased disease build-up in the soil and fast dissemination of the pathogen to new areas.

The first ginger bacterial wilt (BW) were reported from India in 1941 by Thomas, then after a lots of reports came from Australia (Hayward et al., 1967), China (Li et al., 1994), Hawaii (Rosenberg, 1962), Indonesia (Sitepu et al., 1977), South Korea (Choi and Han, 1990), Malaysia (Lum, 1973), Mauritius (Orian, 1953), Nigeria (Nnodu and Emehute, 1988), Philippines (Zehr, 1969)and Japan (Morita et al. 1996). In Ethiopia, bacterial wilt caused by Ralstoniasolanascerum (Smith) has been reported on Potato, Tomato, Pepper, Enset, Banana and Ornamentals but on ginger this is the first report.

Bacterial wilt is the main causal agent of ginger wilt in tropical, subtropical, regions (Agrios, 2005). In the absence of susceptible crops, alternative weed hosts and non-host plants and soil played an important role for the survival of $R$. solanacearum strains (Granada and Sequeria, 1983). Yield losses due to rotting of rhizomes estimated 50\% in Hawi(Yu et al. 2003) and 100\% in India(Dohroo, 1991). 
Though a systemic plant bacteriousis research in Ethiopia was started by Dagnachewyirgu (Stewart and Dagnachew, 1967), Bacterial wilt diseases, caused by R.solanacearum E.F. Smith was first recorded in Ethiopia much earlier on Potato, tomato and eggplant (Stewart, 1956) later it was confirmed by various researchers. The disease is prevalent in many areas at both high and low altitudes (Korobko, 1981 and Stewart, 1956). R.solanacearum E.F Smit grouped in to five races based on the different in host ranges and geographic distributions. According to Kelman (Kelman, 1997), those races principally attack bananas, ornamental planes, potato, ginger and mulberries are race 1 , race 2 , race 3 , race 4 and race 5 respectively. Unlike race 3 biovar $2 \mathrm{~A}$ which have relatively wide host range (Hayward et al., 1967) race 4, of the pathogen has a narrow host range, and restricted to ginger (Kelman, 1997) and limits the production of ginger in the tropics (Paret, et al, 2010;Fikere Lemessa and Zeller, 2007) identified sixty two R. solanacearum strains from Ethiopia and 19 of them grouped in to biovar I and the rest of the strains to biovar II. It was further observed that biovar II strains had limited host range (affecting mainly potato) compared to biovar I strains (affecting eggplant, tomato and potato) but so far race 4 is not yet reported in association with ginger or other crops in Ethiopia.

Moslem Khani et al.,(2005) shown that BW is mainly both seed-borne and soil-borne disease as often spread through latently infected planting materials to new disease free areas or planting on an infected soil. Other than infected seed and soil the pathogen can spread through contaminated run off or rain splash of water or other alternate weed hosts. Rhizomes harvested from contaminated soils by the pathogen, are believed to be potential vehicles and convey the pathogen latently hence, rhizomes with latent infection are highly contributed to disseminate the disease and loss of the produces. Hayward, (1991) reported that, on potato, the pathogen is mainly transmitted through tuber seed. Though there was no study how the disease was prevailed in all ginger growing areas of the country with in short period, this was happened probably because of limited number of varieties (one local "Volvo" and two improved "Yali" and "Boziab") are produced throughout the country hence, the chance of having varietal differences in response to the disease is far remote. In addition farmers may use seeds from their previous harvest which leads to degeneration of seeds due to pathogen accumulation in the tubers and /or in the soil.

Despite the increasing importance of the disease in the country, there was no information generated about the causative agent, distribution, and Ethiology of the pathogen. Hence, the objectives of the study were to survey and map ginger bacterial wilt distribution and identify and characterize the causal agent of wilt diseases of ginger prevailed in the South Nation and Nationality People Regional State

\section{Materials AND Methods}

\subsection{Survey and Mapping}

Survey on the disease of ginger was conducted in the year 2012 and 2014 in 11 zones namely Bench maji, Sheka, ,Kaffa, Dawro, Sidama, Kembatatembaro, Welayta, Hadiya, Gamugofa, Konta and Alaba zones in Southern regional state, Ethiopia (Figure 1). A stratified sampling technique was employed to sample zones and "woredas" and ginger fields were randomly assessed after every 510killo meter. Data on disease prevalence and incidence was collected on 5-10 random spots in X path. A total of 165 ginger producing farmer's field which was found in twenty seven "woredas", nine zones and two special "woredas" in south Nation and Nationality of Peoples' Regional State (SNNPRS) and one zone and one woreda in Gambela regions were assessed. In order to determine the incidence of the disease, field diagnosis was done based on symptoms of the disease. In conditions where distinct symptom to the disease is confusing, a rhizome segment (about 5-6 cm) immersed in the glass of water and watched for milky continuous threads streaming downward from the cut; and the internal tissue was examined for vascular brown ring and creamy bacterial exudates(Hayward, 1964). All surveyed fields were geo referenced to integrate data into GIS for analysis and map the distributions of GBW incidence. Information based on the check list that includes the socio economic aspect and the cropping system was gathered to see how this scenario affects the incidence of the disease. The incidence of bacterial wilt was recorded and calculated based on the description by Horita and Tsuchiya (2001).

$\%$ Wilt incidence $=$ Number of wilted plants in each field $\mathrm{X} 100$

$$
\text { Total number of plants in each field }
$$

Finally average incidence was calculated for each zone. 


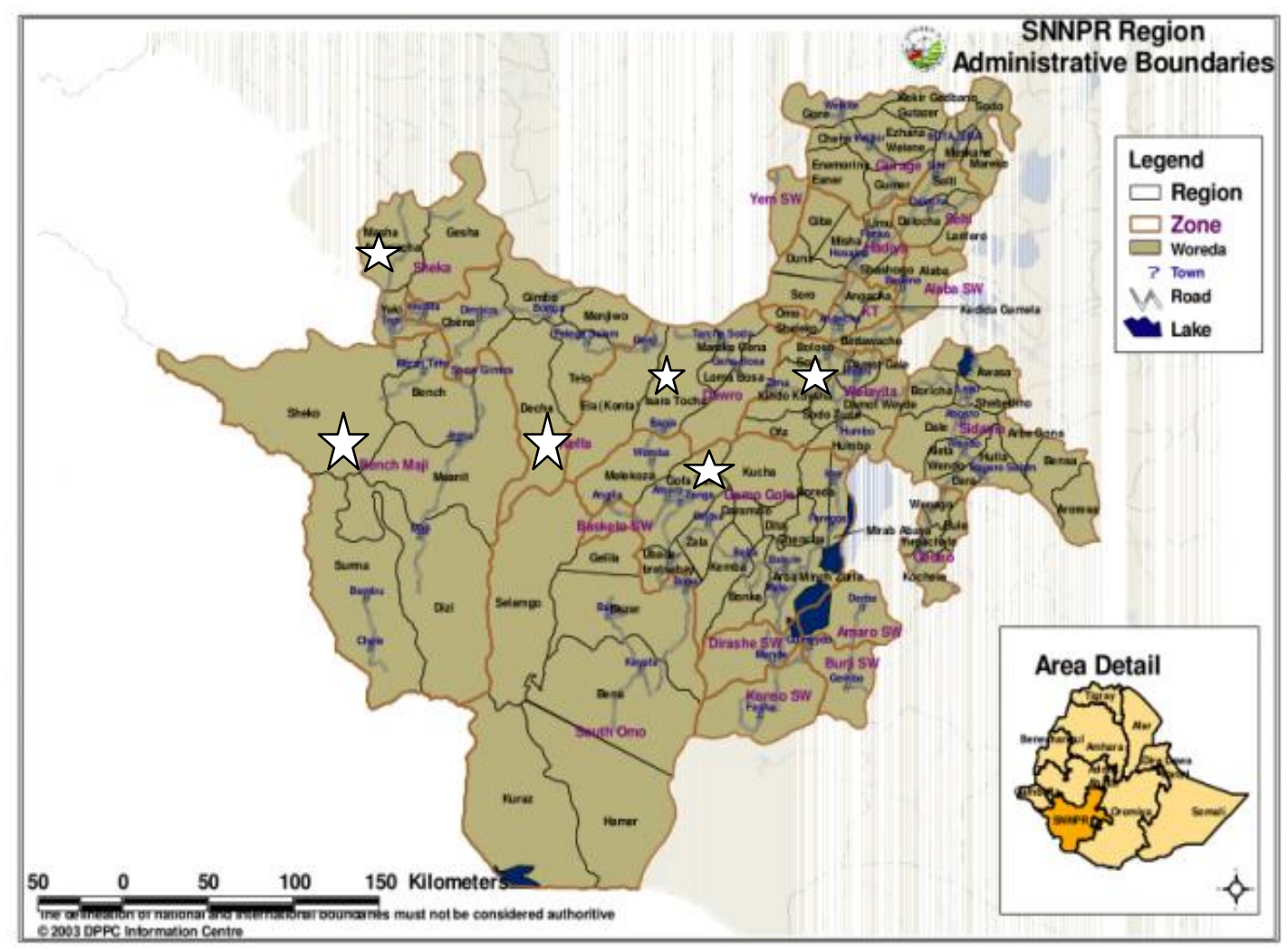

Fig1. Ginger bacterial wilt distribution map in SNNS of Ethiopia Stars indicated that the survey zone

\subsection{Isolation and Identification}

Diseased ginger plant parts (pseudo-steams, and rhizomes) and soil from the rhizospher were collected from the assessed fields. Diagnosis of diseased plants were done by critically observing the wilt symptoms and preliminary field level test, white ooze from a peace of rhizome placed in a glass containing water. Farther the pathogen was isolated from surface sterilized rhizome in Nutrient Agar (NA) media in the laboratory. The plates were then incubated at $28^{\circ} \mathrm{C} \pm 2$ for $24 \mathrm{hrs}$. After the development of the isolates a single colony of each isolate were taken and streak on TriphenylTetrazolium Chloride (TTC) medium as described by Kelman (1954)

\subsection{Pathogenicity Test}

The pathogenicity tests were conducted at Holetta agricultural research center in the green house using isolated bacterium from infected ginger rhizome. For this test, disease free seedlings (having average $10 \mathrm{~cm}$ in length) developed through tissue culture were brought from Jimma agricultural research center, biotechnology laboratory and planted in pots containing $4 \mathrm{~kg}$ of sterilized, sand, soil and compost mixture (1:2:1 ratio). Pots were kept in the green house for two weeks for acclimatization then after, they were brought to cold frame where the temperature $\left(26 \pm 2^{\circ} \mathrm{C}\right)$ and relative humidity $(<85)$ is relatively conducive to the growth of the crop as well as for the development of the pathogen. The bacterial suspension of $R$. solansarumwas prepared in the laboratory and the suspension containing $3.2 \times 10^{6} \mathrm{cfu} / \mathrm{ml}$ were inoculated on three months old seedlings using syringe on the pseudo stem at ground level and soil inoculation was also performed to promote fast infection. Expressions of pathogenicity were monitored after every 5 days.

\subsection{Determination of Biovars}

The isolates of $R$. solanacearumwere differentiated into biovars based on their ability to utilize disaccharides (Cellobiose, lactose, and maltose) and Hexose alcohols (mannitol, sorbitol and dulcitol) as described previously by Hayward (1964). The biovars were determined in the mineral medium (NH4H2PO4 1.0g, KCl 0.2g, MgSO4.7H2O 0.2g, Difcobacto peptone 1.0g, Agar 3.0g and Bromothymol blue $80.0 \mathrm{mg}$ per liter) containing 1\% sugar. About $200 \mu \mathrm{l}$ of the melted medium is dispensed into the wells of microtitre plate. Inoculum for each group of isolates was prepared by 
adding several loop full of bacteria from 24-48 hours old cultures to distilled water to make suspension containing about $3.2 \times 10^{8} \mathrm{cfu} \mathrm{ml}^{-1}$. Then $20 \mu \mathrm{l}$ of bacterial suspension was added to the wells of microtitre plate incubated at $28-32^{\circ} \mathrm{C}$. The tubes were then examined for 3 days after inoculation for a color change due to $\mathrm{pH}$ (Schaadet al., 2078). Hayward, 1964 and 1994; OEPP/EPPO, 2004

\subsection{Races Identification}

Plants used as differential hosts were tomato (LycopersiconesculentumMill.), banana (Musa accuminata), ginger ( $Z$. officinale), and turmeric (Curcuma domestica) seedlings grown in the greenhouse. The pure culture of virulent $R$. solanacearum isolates were reproduced in nutrient agar medium and differential hosts were inoculated with the suspension adjusted to a concentration of $3.2 \times 10^{8} \mathrm{cfu} / \mathrm{ml}$ (Sarma et al., 1978).

\section{RESULT AND DISCUSSIONS}

\subsection{Incidence and Distribution of the Disease}

During field survey, symptoms observed on ginger were slight yellowing and wilting of the lower leaves which progresses upward to the younger leaves followed by a complete yellowing and browning of the entire pseudo-steam. In some instances and fields the entire shoot becomes sagging and the pseudo-steams produce young succulent shoots which are soft and completely rotted and diseased shoots break off easily from the underground rhizome at the soil line. Infected rhizomes showed grayish-brown discoloration and /or soft, water-soaked and rotted symptoms. From the cut surface of diseased rhizome release extensive bacterial ooze that shows slimy, creamy exudates when pressed or immerse in a glass of water.

The disease was observed in all surveyed zones (Table 1). Mean incidence (34.08\%) of the disease recorded in 2012 was increased to $90.74 \%$ in 2014 season. In 2012 season, the maximum disease incidences $(93.7 \%$ and $91.6 \%$ ) were recorded in Bench maji and Sheka zones respectively. The lowest incidence of the disease being in Gamugofa, Hadiya, Sidama and Alaba which had $10.7 \%$, $11.4 \%, 11.3 \%$ and $11.0 \%$.respectively and the rest had in the range of 22.3 to $65.7 \%$.

In the year, 2014, the disease was increased to above and over $78.4 \%$ and the maximum being 99.0 which was recorded in Welayta zone. Survey results of, SNNPRS (Dawro, Wolayta, Kenbatatenbaro, Hadiya, Gomogofa, Konta, Alaba, Sheka, and Bench maji) zone the crop was devastated by the diseases and cause yield loss up to $98 \%$. This was happened probably due to the ideal weather condition for the development of the disease. (Average rain fall, $287.9 \mathrm{~mm}$, Tmax, $27.8^{\circ} \mathrm{C} \& \mathrm{~T} \min$. $17.1^{\circ} \mathrm{C}$ ) and using of latently infected seed rhizome. The pathogen transmitted through rhizome seed caring latent infection (Tall, 1997), Bowman, 1980 reported that $R$. solanacearumis seed and soil born and easily disseminated from one area to the other through planting material.

From the study conducted in the center shows that a sharp relationship was observed between ginger bacterial wilt incidence and the prevailing weather condition (Table 2). The disease on set was found at the end of June to mid of July which is the main rainy season starts as well as warm humid weather dominates. Diseases progress and wilt of ginger continues till September and October. After October the moisture and temperature as well as wilt incidence dramatically reduced. In most cases wilting process of ginger started from end of Jun to July (av. Tmax. $29^{\circ} \mathrm{C}$, Tmin. $16.5^{\circ} \mathrm{C}$ and RF. $234.5 \mathrm{~mm}$ ) when moisture gradually rises. The maximum wilt intensity $98.9 \%$ was recorded during AugustSeptember (Av. Tmax. $29.5^{\circ} \mathrm{C}$ and Tmin. $17^{\circ} \mathrm{C}$ and RF. $207.5 \mathrm{~mm}$ ) and death of such plants ceased at the end of October (Av. Tmax.29.3 ${ }^{\circ} \mathrm{C}$, Tmin. $16.7^{\circ} \mathrm{C}$ and RF. $131.4 \mathrm{~mm}$ ). Due to the increase in rainfall during July-September the active inoculums in the field could easily be transported to nearby fields by rain run-off, and farm activities, these condition increases the incidence, severity and disease distribution (Mondal, Bhattacharya and Khatua, 2004). According to EPPO (2004) The optimum growth temperature of $R$. solanacearumin the tropics were $\left(35^{\circ} \mathrm{C}\right)$ whereas that of strains occurring at higher altitudes in the tropics and in subtropical and temperate areas is lower $\left(27^{\circ} \mathrm{C}\right)$; no growth has been observed at $40^{\circ} \mathrm{C}$ or $4^{\circ} \mathrm{C}$. According to Kelman (1953) Approximate minimal and maximal growth temperature values would be $8-10^{\circ} \mathrm{C}$ and $37-39^{\circ} \mathrm{C}$ respectively. The same symptom which was previously described by Kumar and Sarma (2004) was found widespread in all areas surveyed (Figure ....). Among the different places surveyed, wilt incidence was in range of 93.5 to $10.7 \%$ of which the highest $93.5 \%$ were recorded in Sheka zone whilt the lowest $10.7 \%$ in Gamogofa zone in 2012 season (table 1). The first bacterial wilt were reported from Benchmaji zone Bebeka coffee estate farm, then after it was observed in the neighboring zone sheka and cause up to $67 \%$ yield loss 
Status of Ginger Wilt and Identification of the Causal Organism in Southern Nations Nationality and People Sates of Ethiopia

whereas the diseases were less prevalent $22.3 \%$ around wolayta zone which is the major ginger growing area of Ethiopia; this may be due to the difference in geography, agro-ecology and the prevailing weather condition as suggested by Elphinstone, 2005 (Elphinstone, 2005). According to Yulia and Koki (2015) direct yield losses and incidence by $R$. solanacearum vary widely according to the host, cultivar, climate, soil type, cropping pattern, geography and strain.

At the same year even if the diseases is less prevalent at wolayta area, which has slightly differ in its weather conditions and cropping from Benchmaji and Sheka zones, we collect a total of 234 randomly sampled rhizomes were subjected to the diagnosis and all samples were found infected except samples taken from the research center which had only 5\% of the rhizomes infected (table 2). During the survey some fields where ginger had high wilt incidence, banana, turmeric and/or Enset grown adjacent to ginger fields were found free of the disease that indicate the disease is specific to ginger (Figure 8).

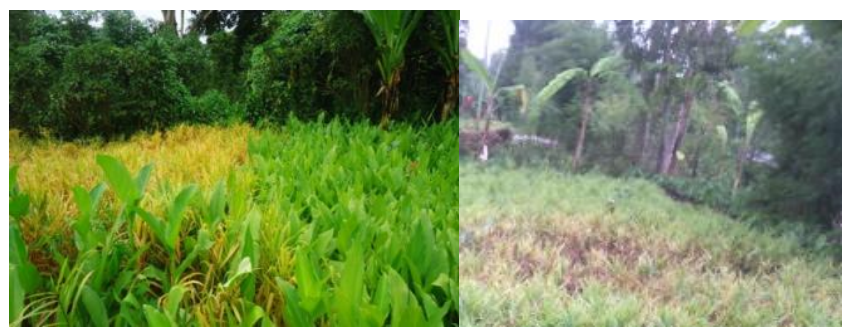

$\begin{array}{ll}\text { (a) Wilted ginger, healthy turmeric and Enset } & \text { (B) wilted ginger and healthy banana }\end{array}$

Fig2. host specificity of ginger bacterial wilt pathogen which didn't attack turmeric and banana

Table .1.incidence of ginger wilt in the SNNPS in 2012 and 2014 main season

\begin{tabular}{|l|l|l|}
\hline & Wilt incidence (\%) \\
\hline Zone & Year & \multicolumn{2}{l|}{} \\
\hline & 2012 & 2014 \\
\hline Bench maji & $91.6 \pm 0.22$ & $89.9 \pm 0.082$ \\
\hline Sheka & $93.7 \pm 0.23$ & $97.4 \pm 0.089$ \\
\hline Majange & $65.7 \pm 0.16$ & $98.8 \pm 0.090$ \\
\hline Kaffa & $21.8 \pm 0.05$ & $78.4 \pm 0.072$ \\
\hline Dawro & $25.6 \pm 0.06$ & $93.7 \pm 0.086$ \\
\hline Sidama & $11.4 \pm 0.03$ & $92.3 \pm 0.085$ \\
\hline Welayta & $22.3 \pm 0.05$ & $99.0 \pm 0.090$ \\
\hline Hadiya & $11.3 \pm 0.03$ & $89.0 \pm 0.082$ \\
\hline Gamugofa & $10.7 \pm 0.03$ & $87.9 \pm 0.081$ \\
\hline Konta & $25.8 \pm 0.06$ & $89.9 \pm 0.082$ \\
\hline Alaba & $11.0 \pm 0.03$ & $78.9 \pm 0.072$ \\
\hline Mean & 34.08 & 90.74 \\
\hline
\end{tabular}

Latent infection in rhizomes was also found very alarming. From 254 rhizomes tested only 51 rhizomes were found free of the pathogen whereas the remaining 203 rhizomes were found carriers of the pathogen (Table ....). Rhizomes from infected plants by the disease are often the carrier of the pathogen as it was reported by Belén, etal. 2010; and Kumar and Sarma, 2004

Table2. percent latently infected rhizomes in different zones

\begin{tabular}{|l|l|l|l|l|l|}
\hline No. & Zone & $\begin{array}{l}\text { Weredas } \\
\text { covered }\end{array}$ & Kebele & $\begin{array}{l}\text { Rhizome } \\
\text { tested }\end{array}$ & $\begin{array}{l}\text { Latent } \\
\text { infection (\%) }\end{array}$ \\
\hline 1 & Hadiya & 7 & 10 & 12 & 100 \\
\hline 2 & Welaita & 2 & 9 & 35 & 100 \\
\hline 3 & KambataTambaro & 3 & 18 & 61 & 100 \\
\hline 4 & Dauro & 7 & 18 & 70 & 100 \\
\hline 5 & Teppi research center & - & - & 56 & 5 \\
\hline Total & & 19 & 55 & 234 & \\
\hline & & & & & \\
\hline Mean & & & & & 81 \\
\hline
\end{tabular}




\subsection{Field Diagnosis Based Identification}

\subsection{Symptom on Above Ground Part}

The wilt symptom on the above ground ginger plant part were found the first wilt symptoms were a slight yellowing and wilting of the lower leaves. The wilt progresses upward, affecting the younger leaves, followed by a complete yellowing and browning of the entire pseudo-steam. Under conditions favorable for disease development, the entire shoot becomes flaccid and wilts with little or no visible yellowing. However, the plant dries very rapidly and the foliage becomes yellow-brown in 5 to 10 days. Wilt of the pseudo-steam advances make young succulent shoots frequently become soft and completely rotted and the diseased shoots break off easily from the underground rhizome at the soil line (fig 4, a , b , c , and d). The same ginger bacterial wilt symptom was described by Kumar and Sarma (2004).

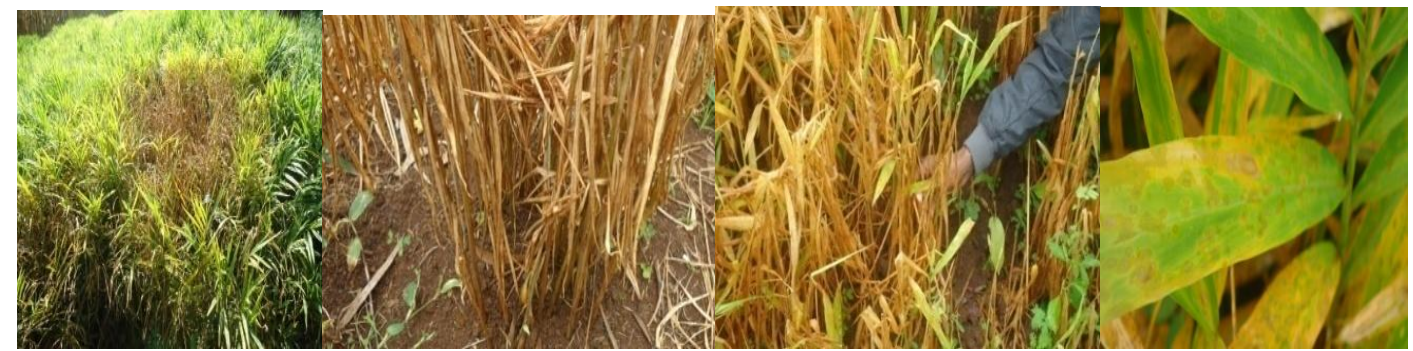

(a),Initial symptom(b), wilted tiller

(c), diseased shoots

(d), Water scoked spots

break off easily on leaves

Fig.3. areal symptom of ginger bacterial wilt in the production fields

\subsubsection{Diagnosis on Rhizomes}

From the analysis of underground plant part symptom, grayish-brown discoloration of the rhizomes were seen at early stage of infection, in advanced stage of the disease development, major part of the rhizome became discolored, soft, water-soaked and rotted(Fig 5, f ). From the cut surface of diseased rhizome extensive bacterial ooze that shows slimy, creamy exudates when pressed or immerse in a glass of water (Fig 5, g) the same result have been reported by BelénÁlvarez, Elena G. Biosca, and María M. Lópe. (2010) and Kumar and Sarma (2004)

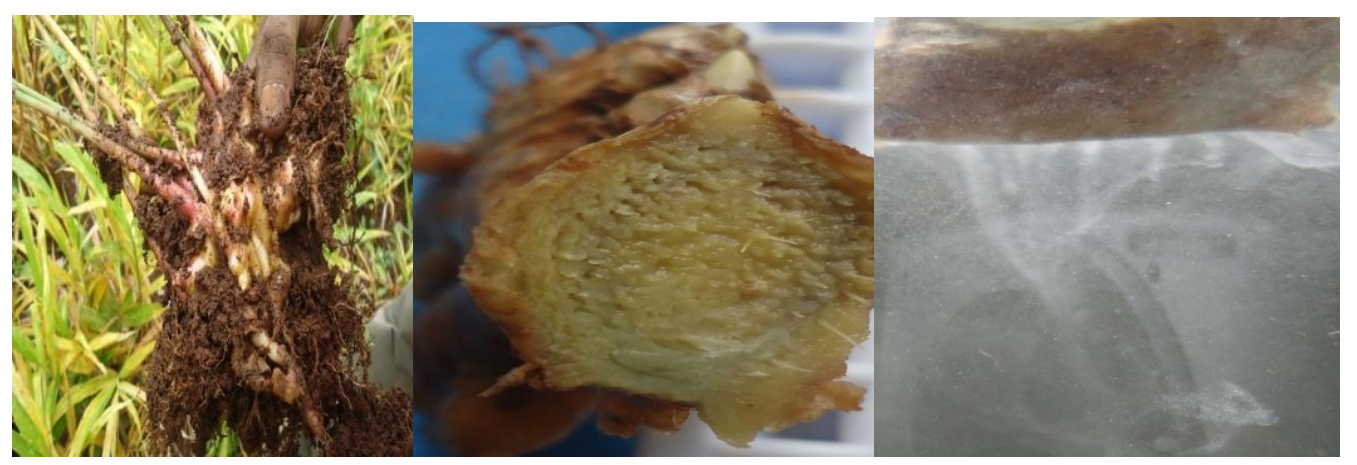

(e), Infected rhizome (f), Rotted rhizome (g), Bacterial streaming from an infected ginger rhizome

Fig.4. below ground symptom of ginger bacterial wilt on rhizome as observed during field diagnosis

The symptoms observed on infected ginger plants at initial developmental stage of the crop on leaves, pseudo-stems and rhizomes was identical to the descriptions of the symptom given by Trujillo, (1964). In vascular tissue, fine milky white strands, compound of mass of bacteria in extra cellular slime, stream down from the cut ends of xylem vessels. This bacterial exudate combined with symptoms observed on leaves enables to differentiate from other wilt diseases caused by fungus (Hayward, 1964).

\subsection{In Vitro Identification}

Since the diseases is new to Ethiopia a team of different discipline mobilized to check and identify the true causal agent of ginger wilt diseases. As a result field diagnosis for characteristic symptom and isolation frequency as well as existence of minimal number of parasitic nematode in 100gram of soil 
Status of Ginger Wilt and Identification of the Causal Organism in Southern Nations Nationality and People Sates of Ethiopia

confirms that nematodes were not causal agents. Isolation of fungal pathogen from infected ginger samples shows that none appeared. Which confirm that fungi were hardly suspected as causal agent of the diseased happened, The samples were also diagnosed for presence and isolation of bacteria, which reviled that similar bacterial colonies were observed per all samples of all plant parts (Leaf, Rhizome and Pseudo stem) (Ambo plant protection research Center, result of diagnosis report unpublished).

\subsubsection{Culture based identification}

in vitro, on tetrazolium chloride (TZC) media the culture had fluidal, presents irregular shape and white with pink centered colonies, which is similar with the description of Kelman (1954) (Fig 6).

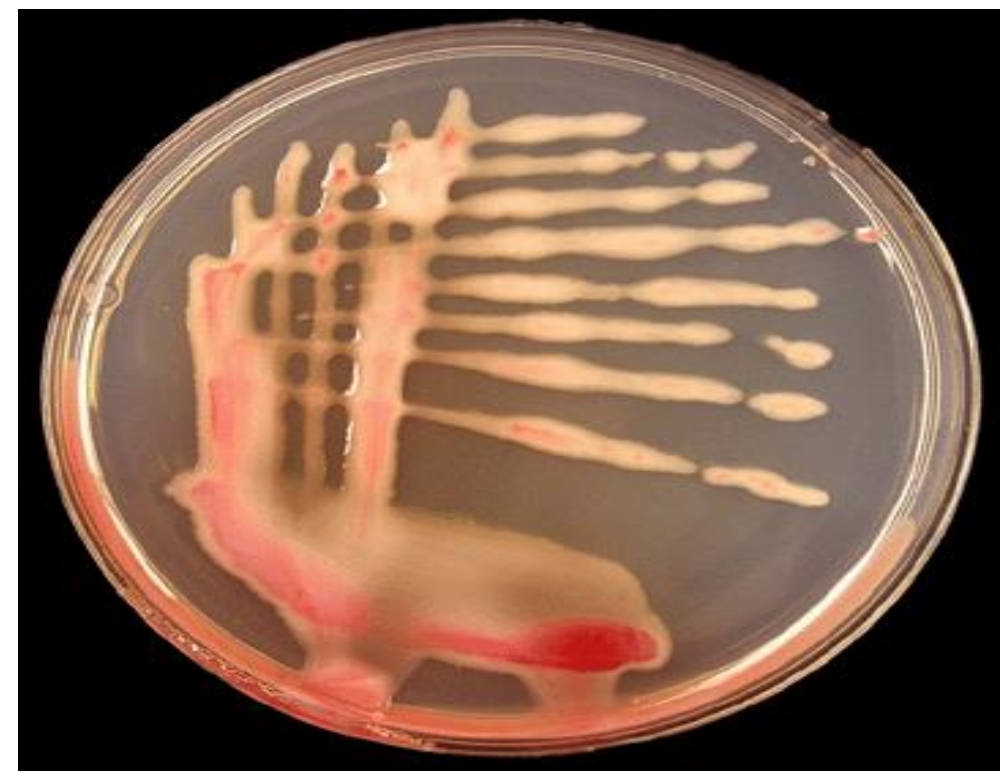

Fig.5. virulent colonies of $R$. solanacearumin TZC agar medium

The colony after 48 hours of incubation had a color of white with pink centers which indicated that the isolate is virulent $R$. solanascearum (Fig 6) which is similar to previous reports by Hayward, (1964).

\subsection{Pathogenicity Test}

Pathogenicity test of $R$. solanacearun reviled that wilt of ginger occur within 7 - 10 days after inoculation (Fig 6). The result were found in range of pathogenecity study in India and concluded that wilt of ginger occur within 5-7 days after inoculation (Kumar and Sarma, 2004)

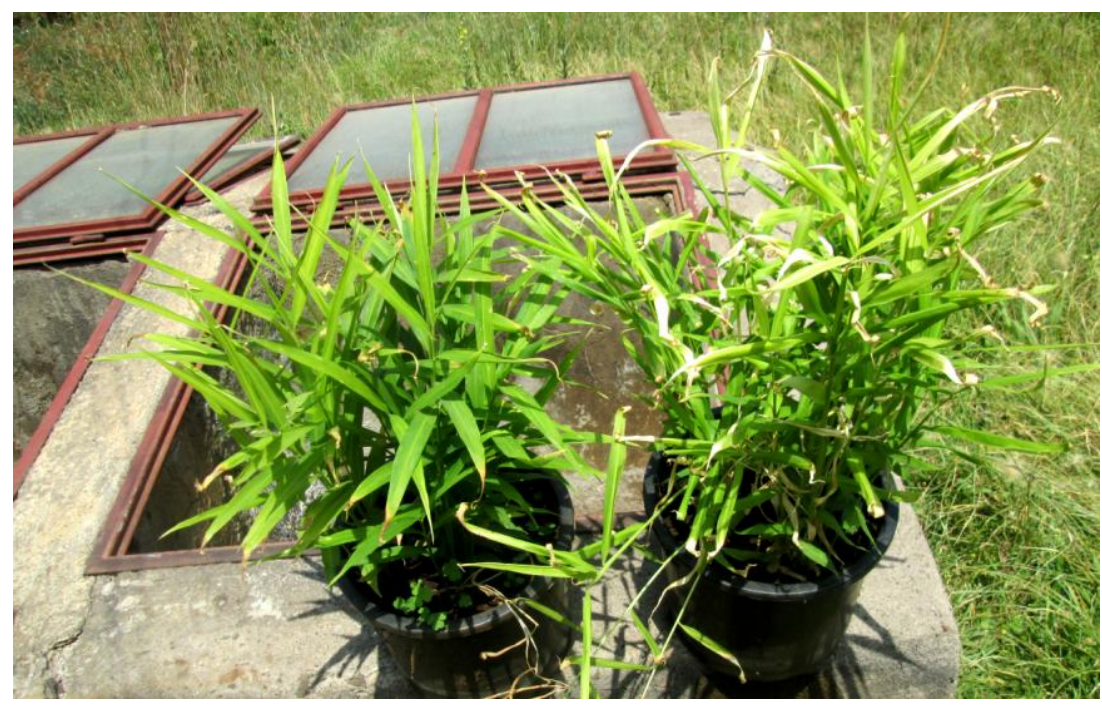

Figure6. (A), un inoculated without the symptom of the disease (B), disease symptom development 5 days after inoculation 


\subsection{Biovar Differentiation}

The biovar of $R$. solanacearumisolates was identified by utilization of disaccharides and hexose alcohols. The result of the biovar test showed that all of R.solanacearumisolates oxidized disaccharides (Cellobiose, lactose, and maltose) and hexose alcohols (manitol, sorbitol and dulcitol) within 3-5days (Table 2). The oxidation reaction was indicated by the change of color. The results revealed a change of color blue to yellow color indicating the oxidization of sugars by bacterial isolates. Therefore, all groups of R.solanacearumisolates belong to biovar III as shown in (Table 2). The differentiation of biovars of $R$. solanacearumbased on the utilization of carbohydrates was reported previously by Hayward (1964), Heet al. (1983) and Kumar and Sarma, (2004). They observed that biovar III oxidizes both disaccharides and hexose alcohols whereas Biovar I oxidize hexose alcohols but not disaccharides, biovar II oxidizes only disaccharides and biovar IV oxidizes only alcohols.

The $R$. solanacearum isolate from different geographic origins of Ethiopia confirm that all the isolates are Biovar 3. This could be due to the increasing of latently infected seed rhizome exchange from one location to another, which indicates the population is clonally propagated and transmitted. Large-scale cultivation of ginger in Ethiopia is mainly through the seed rhizome material brought from the predominant ginger growing locations, particularly wolayta (Boloso sore and boloso bombe) and Yekiworeda, It is likely that the pathogen is spread throughout ginger growing regions and within the locality. This strains causing bacterial wilt of ginger in Ethiopia is similar to that of Indian strain which is belong to biovar 3 that causes wilt in 5-7 days (Kumar. and Sarma, 2004).

Table3. classification of the pathogen using biochemical test

\begin{tabular}{|l|l|l|l|l|l|l|}
\hline \multirow{2}{*}{ Biochemical } & \multicolumn{9}{l}{ Isolate } & \multicolumn{2}{l|}{ Biovar } \\
\cline { 2 - 7 } & Wolayta & \multicolumn{1}{l|}{ Yeki } & Benchmaji & \multicolumn{2}{l|}{ Majang } & \\
\hline Acid from: Hexose alcohols & + & + & + & + & III \\
\hline Mannitol & + & + & + & + & III \\
\hline Sorbitol & + & + & + & + & III \\
\hline Dulcitol & + & + & + & + & III \\
\hline Disaccharides & + & + & + & + & III \\
\hline Cellobiose & + & + & + & + & III \\
\hline Lactose & + & + & + & + & \\
\hline Maltose & + & & & &
\end{tabular}

\subsection{Race Identification}

The result race identification showed that $R$. solanacearum isolated from wilted ginger ( $Z$. officinale) infect and developed symptom only on ginger and gone within 12 days after observing the first symptom. But, tomato (LycopersiconesculentumMill.), banana (Musa accuminata), and turmeric (Curcuma domestica), were not develop any symptom and stayed healthy. $R$. solanacearum have different host ranges and geographic distributions; race 1,2,3, 4 and 5 principally attacks bananas, ornamental planes, potato, Ginger and mulberries respectively (Kelman, 1997). R. solanacearum race 4 was found restricted to ginger (Paret, et al, 2010). According to Kumar and Sarma, (2004) race 4 didn't attack banana, potato, tomato, pepper and curcuma and cause wilt on ginger within 5 to 7 days, The pathogens was identified as race 4 based on their specific pathogenicity to Zingiberaceae crops as it was reported by Morita et al. 1996; Tsuchiya et al. 1999 \&2005; Yano et al., 2005 and 2011.

Table4. Correlation of GBW incidence with temperature (maximum and minimum) and rain fall

\begin{tabular}{|c|c|c|c|c|c|}
\hline & & $\mathrm{RF}$ & Tmin & Tmax & GBW incidence \\
\hline \multirow{3}{*}{ RF } & Pearson Correlation & 1 & -.057 & .227 & $.991^{* * *}$ \\
\hline & Sig. (2-tailed) & & .785 & .275 & .000 \\
\hline & $\mathrm{N}$ & 25 & 25 & 25 & 25 \\
\hline \multirow{3}{*}{$\mathrm{T} \min$} & Pearson Correlation & -.057 & 1 & -.024 & -.106 \\
\hline & Sig. (2-tailed) & .785 & & .909 & .614 \\
\hline & $\mathrm{N}$ & 25 & 25 & 25 & 25 \\
\hline \multirow{3}{*}{$\mathrm{T} \max$} & Pearson Correlation & .227 & -.024 & 1 & .191 \\
\hline & Sig. (2-tailed) & .275 & .909 & & .359 \\
\hline & $\mathrm{N}$ & 25 & 25 & 25 & 25 \\
\hline \multirow{3}{*}{ GBW incidence } & Pearson Correlation & $.991^{* * * * 4}$ & -.106 & .191 & 1 \\
\hline & Sig. (2-tailed) & .000 & .614 & .359 & \\
\hline & $\mathrm{N}$ & 25 & 25 & 25 & 25 \\
\hline
\end{tabular}


the correlation result of bacterial wilt incidence to weather parameter (Rain fall, Temperature maximum and Temperature minimum) at Tepi National Spices Research Center shows that high Rain fall and high temperature were found a positive significant correlation whereas, low daily temperature and low rainfall were found negatively correlated. It also noted that $\mathrm{PH}$, Soil and air temperature and moisture, have great influence and relationship on the survival and incidence of the pathogen (OEPP/EPPO., 2004 and Kelman, 1953).

\section{Conclusion}

Bacterial wilt is becoming a threat to ginger production in Ethiopia and farmers reported to have total frailer of the crop due to the disease. This study revealed that the disease that threat ginger in Ethiopia is caused by Ralstoniasolanacearumbiovar III race 4 and the diseases were distributed in major ginger growing areas of the region. Since no resistance genotype was found in Ethiopia and the nature of the bacteria is difficult to control by chemical means an integrated management program requires. Since the pathogen is soil and seed born, research should focus on internal and external quarantine, control of the disease using soil amendments, biological control agents like Thricoderma and disease free seed scheme ought to get high priority. Moreover, the disease is aggravated by recycling of seed rhizomes and farmers lack the knowledge on the nature and lifecycle of the pathogen hence, the advantage of the use of healthy planting materials need aggressive intervention to increase awareness of farmers on seed quality. Generally, since, the pathogen spread at very fast rate in the country at present, it is high time to project research on the control strategies of the disease.

\section{REFERENCES}

[1] Agrios, G.N., 2005. Plant Pathology. 5th Edn., Academic Press, New York, USA., ISBN: 13 9780120445653 , Pages 922.

[2] BelénÁlvarez, Elena G. Biosca, and María M. Lópe. 2010. On the life of Ralstoniasolanacearum, a destructive bacterial plant pathogen current research, technology and education topics in applied microbiology ad microbiology, @ forma tec.

[3] BOARD (SNNPRS Bureau of Agriculture and Rural Development) (2008). Unpublished data.

[4] Choi, J.E., and Han, K.S. (1990) Bacterial soft rot and rhizome rot caused by Erwiniacarotovora subsp. carotovora, Pseudomonas marginalis and P. solanacearum. Korean J. Plant Pathol., 6 (3), 363-368.

[5] Dagnachew, Y., and Bradbury, J.F. 1968. Bacterial wilt of Enset (Ensetventricosum) incited by Xanthomonascampestrissp. Phytopathology 59:111-112

[6] Denny T.P. and Hayward A.C, 2001. Ralstoniasolanacearum. Pages 151-174 in: Lab Guide for Identification of Plant Pathogenic Bacteria. N. W. Schaad et al. eds. 3rd ed. The American Phytopathological Society, St. Paul, MN, 2001.

[7] Dohroo, N.P. (1991) New record of bacterial wilt of ginger in Himachal Pradesh. Indian Phytopathology. North Zone Meeting, April 29-30, p. 16 (Abst.).

[8] Elphinstone JG 2005. The current bacterial wilt situation: a global overview. In: Allen C, Prior P, Hayward AC, eds. Bacterial wilt disease and the Ralstoniasolanacearumspecies complex. St. Paul, MN: APS Press, 2005:9.

[9] EndriasGeta and AsfawKifle. 2011, Production, processing and marketing of ginger in Southern Ethiopia. Journal of Horticulture and Forestry Vol. 3(7), pp. 207-213, July 2011 ISSN 2006-9782 (C2011 Academic Journals

[10] EPPO. 2004. EPPO Standards PM 7/21. Diagnostic protocols for regulated pests: Ralstoniasolanacearum. EPPO Bull 34:173-178.

[11] FikreLemessa\& W. Zelle W, 2007. Pathogenic characterisation of strains of Ralstoniasolanacearumfrom Ethiopia and influence of plant age on susceptibility of hosts against $R$. solanacearum Journal of Plant Diseases and Protection, 114 (6), 241-249, 2007, Eugen Ulmer KG, Stuttgart

[12] Granada, G.A. and L. Sequeira, 1983. A new selective medium for Pseudomonas solanacearum. Plant Dis., 67: 1084-1088.

[13] Hayward, A.C. (1964) Characteristics of Pseudomonas solanacearum. J. Appl. Bacteriol., 27(2), 265-277. 
[14] Hayward, A.C., Moffett, M.L., and Pegg, K.G. (1967) Bacterial wilt of ginger in Queensland. Queensland J. Agric. Animal Sci., 24, 1-5.

[15] Hayward AC. Systematics and phylogeny of Pseudomonas solanacearum and related bacteria. In: Hayward AC, Hartman GL, editors. Bacterial Wilt: The Disease and its Causative Agent, Pseudomonas solanacearum. Wallingford, UK: CAB International; 1994. pp. 123-135.

[16] He, L.Y., L. Sequeira, A. Kelman, 1983: Characteristics of strains of Pseudomonas solanacearumfrom China. Plant Dis. 67, 1357-1361.

[17] Horita, M., Tsuchiya, K. 2001. Genetic diversity of Japanese strains of Ralstoniasolanacearum. Phytopathology 91, 399-407

[18] Kelman A. 1953. The bacterial wilt caused by Pseudomonas solanacearum. A literature review and bibliography. Raleigh, N.C.: North Carolina State College

[19] Kelman, A. (1954) The relationship of pathogenicity in Pseudomonas solanacearum to colony appearance on tetrazolium medium. Phytopathology, 44, 693-695.

[20] Kelman, A.1997. One hundred and one years of research on bacterial wilt. Pages1-5 In: Bacterial Wilt: Molecular and Ecological

[21] Korobko, A.P. 1981. Studying bacterial diseases and working out methods for their control on pepper and potato in Ethiopia, Scientific psychopathological laboratory progress report for the period 1981. Ambo, Ethiopia.

[22] Kumar, A., and Sarma, YR. (2004) Characterization of Ralstoniasolanacearum causing bacterial wilt of ginger. Indian Phytopathol., 57, 12-17.

[23] Li, B.T., Chen, X.W., and Wand, C. (1994) The occurrence and control methods for bacterial rot of ginger (Pseudomonas solanacearum) Bull. of Agric. Sci. Technol. 3, 30.

[24] Lum, K.Y (1973) Cross inoculation of Pseudomonas solanacearum from ginger. MARDI Res. Bull., 1, 15-21.

[25] Moslem Khani, K.J. Mozafari and Alizadeh. 2005. Diagnosis of Ralstoniasolanascearum in potato seed tubers and soil. Using PCR technique. Iran J. Plant Pathol., 41:215-228.

[26] Morita, Y., Yano, K., Tsuchiya, K., and Kawada, Y. 1996. Bacterial wilt of Curcuma alismatifoliacaused by Pseudomonas solanacearum. Proceedings of the Association of Plant Protection Shikoku 31:1-6 (in Japanese).

[27] Mondal B, Bhattacharya R, Khatua DC (2004). Role of infected rhizome on incidence and severity of bacterial wilt of ginger. J. Interacad. 8(3): 480-482.

[28] Nnodu, E.C., and Emehute, J.K.U. (1988) Diseases of ginger and their control. In: Proceedings of the First National Ginger Workshop. Nigeria, Oct. 17-21, pp. 80-84.

[29] Orian, G. (1953) Botanical Division Report: Department of Agriculture, Mauritius, 1952, pp. 3740

[30] OEPP/EPPO. 2004. Diagnostic protocols for regulated pests/Protocoles de diagnostic pour les organismesréglementés. R. solanacearum. Bulletin OEPP/EPPO Bulletin 34, $173-178$.

[31] Paret ML, Cabos R, Kratky BA, Alvarez AM, 2010. Effect of plant essential oils on Ralstoniasolanacearum race 4 and bacterial wilt of edible ginger. Plant Dis. 94:521-527.

[32] Rosenberg, M.M. (1962) Report of the Hawaii Agricultural Experimental Station for the biennium ending June 30, 1962, University of Hawaii, Honolulu.

[33] Sarma, Y.R., Indrasenan, G., and RohiniIyer, R. (1978) Bacterial wilt of ginger (Zingiberofficinale). Indian Arecanut Spices Cocoa J., 2, 9-11.

[34] Schaad, N. W., Takatsu, A., and Dianese, 1. C. 1978. Serological identification of strains of Pseudomonassolanacearumin Brazil. In Proceedings of the fourth international conference of plant pathogenic bacteria. Angers, France, 295-300.

[35] Sitepu, D., Oesman, M., and Suprapto, D.M. (1977) Masalhpenyakitjahe di Kuningan. Paper presented at a seminar held by LPTI Sub Station Tanjungkarang, Lampung.

[36] Stevenson, W. R., Loria, R., Franc, G. D., and Weingartner, D. P. 2001. Compendium of Potato Diseases, 2nd Edition. APS Press.

[37] Stewart R.B. and Dagnachew Y.1967. Index of plant disease in Ethopia . Experiment station Bulletin No. 30, Debrezeit, Ethiopia. Pp79-81. 
[38] Stewart, R.B. 1956. Some plant diseases occurring in Kefa province, Ethiopia. College of agriculture, Alemaya, Ethiopia. Pp58-60

[39] Suslow, T. V. and Schroth, M. N. 1982. Rhizobacteria of sugar beets: Effects of seed application and root colonization on yield. Phytopathology 72:199-206.

[40] Thomas, K.M. (1941) Detailed Administration Report of the Government Mycologist for the Year 1940-41, pp. 153-154.

[41] Trujillo, E. E. 1964. Description of the disease symptoms progress of bacterial wilt of ginger. http://www.ctahr.hawaii.edu/dnn/Portals /43/C2

[42] Tsuchiya, K., Yano, K., Horita, M., Morita, Y., Kawada, Y. and C. M. d'Ursel., 2005. Occurrence and epidemic adaptation of new strains of Ralstoniasolanacearum associated with Zingiberaceae plants under agro-ecosystem in Japan. In Bacterial Wilt Disease and the Ralstoniasolanacearum Species Complex, eds. Allen, C., Prior, P. \& Hayward, A. C., American Phytopathological Society, St. Paul, MN, USA, 463-469.

[43] Tsuchiya, K., Yano, K., Horita, M., Morita, Y., Kawada, Y. and d'Ursel, C. M. 1999. Occurrence of bacterial wilt of ginger in Japan. Annals of the Phytopathological Society of Japan 65: 363.

[44] Yano, K., Kawada, Y., Horita, M., Hikichi, Y., and Tsuchiya, K. 2011. Phylogenetic discrimination and host ranges of Ralstoniasolanacearum isolates from Zingiberaceae plants. Japanese Journal of Phytopathology 77:88-95.

[45] Yano, K., Kawada, Y., Tsuchiya, K., and Horita, M. 2005. First report of bacterial wilt of mioga (Zingibermioga) caused by Ralstoniasolanacearum in Japan. Japanese Journal of Phytopathology 71:179-182.

[46] Yu, Q., A.M. Alvarez, P.H. Moore, F. Zee and M.S. Kim et al., 2003. Molecular diversity of Ralstoniasolanacearum isolated from ginger in Hawaii. Phytopathology, 93: 1124-1130.

[47] Yuliar, YanetriAsi Noon and Koki Toyota, 2015. Recent Trends in Control Methods for Bacterial Wilt Diseases Caused by Ralstoniasolanacearum Microbes Environ. 2015 Mar; 30(1): $1-11$.

[48] Zehr, E.I. (1969) Bacterial wilt of ginger in the Philippines. Philippines Agriculturist, 53 (3\&4), 224-227. 